\title{
Determination of Adenosine Phosphates in Whole Blood by Capillary Zone Electrophoresis ${ }^{1}$ )
}

\author{
Jaromir Kamarýt ${ }^{1}$, Milada Muchová ${ }^{2}$ and Jaroslav Stejskal ${ }^{1}$ \\ 1 Research Institute of Child Health, Brno, Czech Republic \\ 2 Obstetric and Gynaecological Clinic, Department of Neonatology, University Hospital, Brno-Bohunice, \\ Czech Republic
}

Summary: The pool of chemical energy in an organism represented by high-energy compounds can be assessed by means of adenosine triphosphate (ATP) determination in whole blood and tissues. The elegant manner for the determination of adenosine phosphates (ATP, ADP, AMP) in a single assay is offered by the technique of capillary zone electrophoresis. For this purpose, the BioFocus 3000 Capillary Electrophoresis System (BIORAD Laboratories, Inc., Hercules, CA, USA) was used. For the construction of calibration curves, pure preparations of ATP, ADP and AMP were analyzed. The method was used for adenosine phosphates determination in the umbilical blood samples from physiological and immature newborns. Capillary zone electrophoresis enables a specific and simultaneous determination of adenosine phosphates and, thus, monitoring of unusual metabolic situations.

\section{Introduction}

The determination of adenosine phosphates concentrations, especially of adenosine triphosphate (ATP), in whole blood and various tissues can be used for estimating the state of the pool of chemical energy in an organism. ATP represents the energetic currency of the cell, and is a measure of exergonic biochemical processes. Hypoxaemia influences the endothelial cells - interface between blood and tissues - and the decrease of ATP content alters their functions and can seriously impair organs (1).

In this study, a simplified approach using capillary electrophoresis for adenosine phosphate determination in whole blood within a single analysis was taken. The method is considered helpful for evaluation of the anoxic period during the birth period and of the oxygen supply to organs of newborns and preterm babies during the first days of life (2). Capillary electrophoresis for the separation of purine bases and nucleosides in human cord plasma was used by Grune et al. (3), however, rather with regard to other purine compounds than nucleotides. Dawson et al. developed a capillary electrophoresis method using an uncoated capillary to resolve potential impurities in a phosphonate analogue of adenosine triphosphate (4).

\footnotetext{
1 The study has been supported by Grant No. 302/93/2534 from Grant Agency of Czech Republic.
}

\section{Experimental}

\section{Apparatus}

A BioFocus 3000 Capillary Electrophoresis System (BIO-RAD Laboratories, Inc., Hercules, CA, USA) was used for analyses. The fused silica capillaries as capillary cartridges $(24 \mathrm{~cm} \times 25 \mu \mathrm{m}$, coated) are available from BIO-RAD Laboratories. The instrument was run according to the manual of the producer (5). Many valuable and important notions about the capillary electrophoresis techniques were obtained from the monography of Landers and coauthors (6).

\section{Chemicals}

Adenosine 5'-triphosphate disodium salt $\times 3 \mathrm{H}_{2} \mathrm{O}$ and adenosine 5'monophosphate disodium salt $\times 6 \mathrm{H}_{2} \mathrm{O}$ were obtained from Boehringer Mannheim $\mathrm{GmbH}$, Germany. Adenosine 5'-diphosphate sodium salt was obtained from SIGMA Chemical Co., St. Louis, Mo, USA, perchloric acid $70 \%(=700 \mathrm{~g} / \mathrm{kg})$ was purchased from Carlo Erba, Milano, Italy, triethanolamine hydrochloride and potassium carbonate anhydrous from FLUKA, Buchs, Switzerland, $0.23 \mathrm{~mol} / \mathrm{l}$ borate buffer $\mathrm{pH} 7.8$ was modified from the original $0.3 \mathrm{~mol} / \mathrm{l}$ borate buffer $\mathrm{pH} 8.5$ provided by BIO-RAD Laboratories, CA, USA.

\section{Sample pretreatment}

The samples of heparinized blood were deproteinized immediately after being taken, with $1: 20$ diluted perchloric acid $(700 \mathrm{~g} / \mathrm{kg})$ in a 1: 1 ratio. After centrifuging for $10 \mathrm{~min}$ at $4500 \mathrm{~g}$, four parts of a supernatant were neutralized (in an icebath) with one part of a $1 \mathrm{~mol} / \mathrm{l}$ solution of triethanolamine hydrochloride and $1.3 \mathrm{~mol} / \mathrm{l} \mathrm{po}-$ tassium carbonate under simultaneous precipitation of perchloric acid. The mixture of $50 \mu \mathrm{l}$ supernatant and $5 \mu \mathrm{l}$ operational 0.23 $\mathrm{mol} / \mathrm{l}$ borate buffer $\mathrm{pH} 7.8$ was analyzed. The same procedure ivas used for various concentrations of pure preparations of adenosine phosphates taken as a standard sample set.

Analysis conditions

Buffer, samples, and all flushing solutions were used after filtration through a $0.45 \mu \mathrm{m}$ filter (Micro Prep-Disc BIO-RAD) and deaera- 
tion under reduced pressure (water aspiration pump). For optimal performance, the capillaries were preconditioned with $0.1 \mathrm{~mol} / \mathrm{l}$ $\mathrm{NaOH}$ for $2 \mathrm{~min}$, with deionized water for $2 \mathrm{~min}$ and, finally, $3 \mathrm{~min}$ with operational borate buffer $0.23 \mathrm{~mol} / \mathrm{l}, \mathrm{pH} 7.8$ before the first use. Between runs, the capillaries were purged for $1 \mathrm{~min}$ with deionized water, $1 \mathrm{~min}$ with $0.1 \mathrm{~mol} / \mathrm{l} \mathrm{NaOH}, 1 \mathrm{~min}$ with deionized

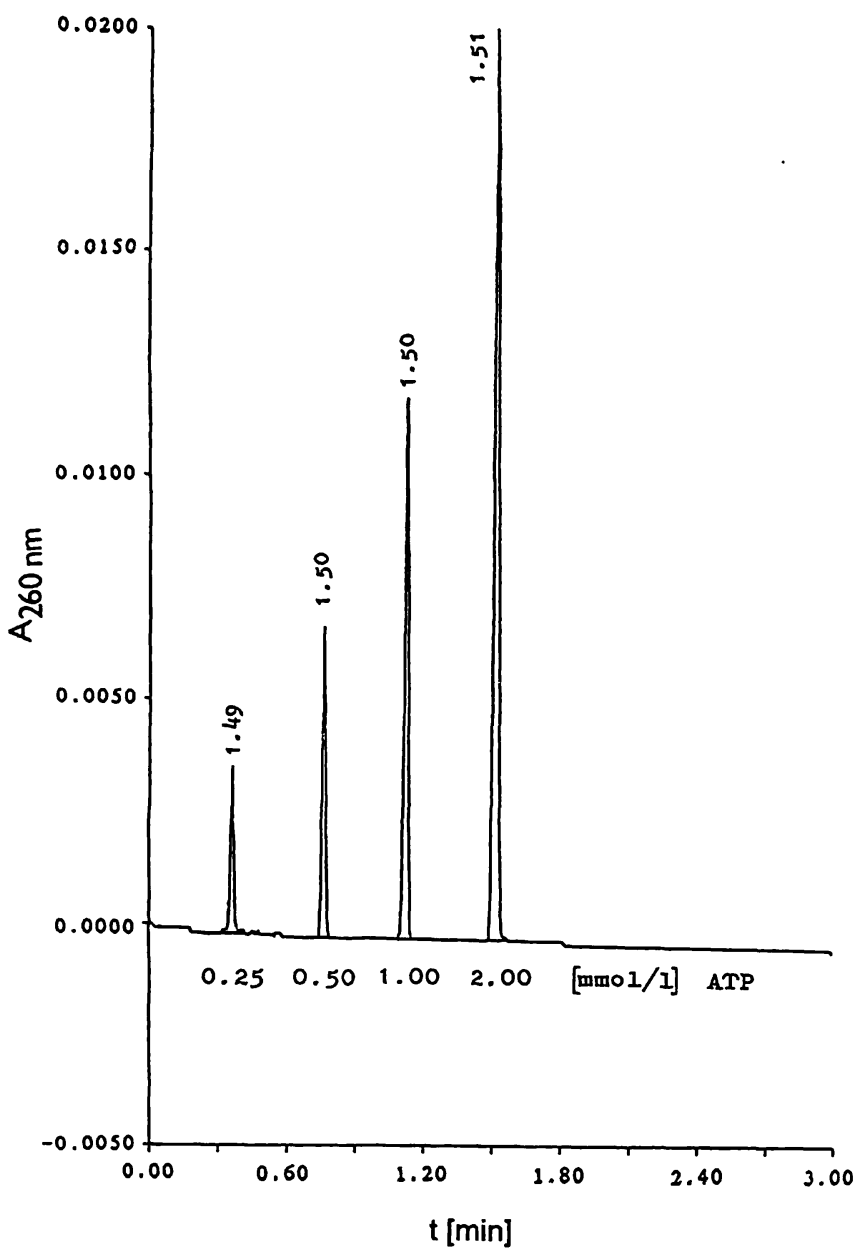

Fig. 1 a The analyses of ATP standard solutions with concentrations between 0.25 and $2.00 \mathrm{mmol} / \mathrm{l}$. Separation conditions: coated silica capillary $(25 \mu \mathrm{m} \mathrm{I.D.} \times 24 \mathrm{~cm}, 19.4 \mathrm{~cm}$ to the window). Operational borate buffer $0.23 \mathrm{~mol} / \mathrm{l}, \mathrm{pH} 7.8$. Injection of sample 20 psi $\left(14 \times 10^{3} \mathrm{~kg} / \mathrm{m}^{2}\right) \times \mathrm{s}, 20^{\circ} \mathrm{C}, 20 \mathrm{kV}$, polarity $\Theta \rightarrow \oplus$, detection wavelength $260 \mathrm{~nm}$.

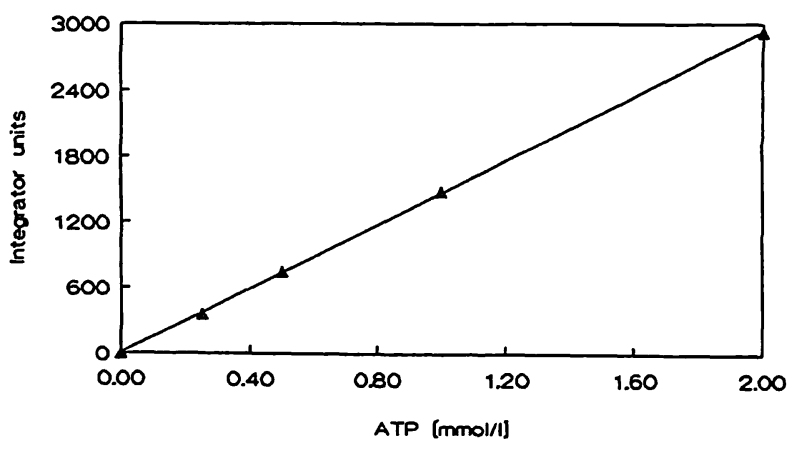

\begin{tabular}{llc}
\hline No. & ATP $(\mathrm{mmol} / \mathrm{l})$ & Integrator units \\
\hline 1 & 0.00 & 0.0 \\
2 & 0.25 & 362.0 \\
3 & 0.50 & 746.4 \\
4 & 1.00 & 1485.8 \\
5 & 2.00 & 2923.2 \\
\hline
\end{tabular}

Fig. 1 b Calibration graph of ATP. Data from analyses see figure $1 \mathrm{a}$. water and $2 \mathrm{~min}$ with run buffer. The separations were run with the direction of electrode polarization $\Theta \rightarrow \oplus$, at $20^{\circ} \mathrm{C}$ capillary cartridge and carousel temperature, constant voltage $20 \mathrm{kV}$ ( $3 \mathrm{~min}$ ) or $10 \mathrm{kV}(6 \mathrm{~min})$ respectively. The samples were injected into the capillary with a pressure of 5 psi $\left(3.5 \times 10^{3} \mathrm{~kg} / \mathrm{m}^{2}\right) 4$ seconds (pressure time inject constant 20), detection at $260 \mathrm{~nm}$.

\section{Results}

The results for ATP standard solutions with concentrations between 0.25 and $2.0 \mathrm{mmol} / \mathrm{l}$ and of the concentration ranges of adenosine nucleotides (ATP, ADP, AMP) expected in whole cord blood deproteinates are shown in figures $1 \mathrm{a}$ and $2 \mathrm{a}$ together with calibration graphs (figs $1 \mathrm{~b}$ and $2 \mathrm{~b}$ ). The linearity and reproducibility of migration times is evident. The results in figure 2 a show ATP, carrying near the neutral $\mathrm{pH}$ four net negative charges as the first nucleotide passing the detector. Adenosine diphosphate with three, and AMP with two, net negative charges sucessively pass the detector through the coated capillary with the direction of electrode polarization $\ominus \rightarrow \oplus$. Table 1 shows the migration times (mean $\pm \mathrm{SD}$ ) and apparent electrophoretic mobilities of adenosine phosphates separated by capillary electrophoresis under the conditions described in figure $2 \mathrm{a}$. The reproducibility of the migration times and peak areas were investigated for a single blood sample analyzed several times (tab. 2). The identity of nucleo-

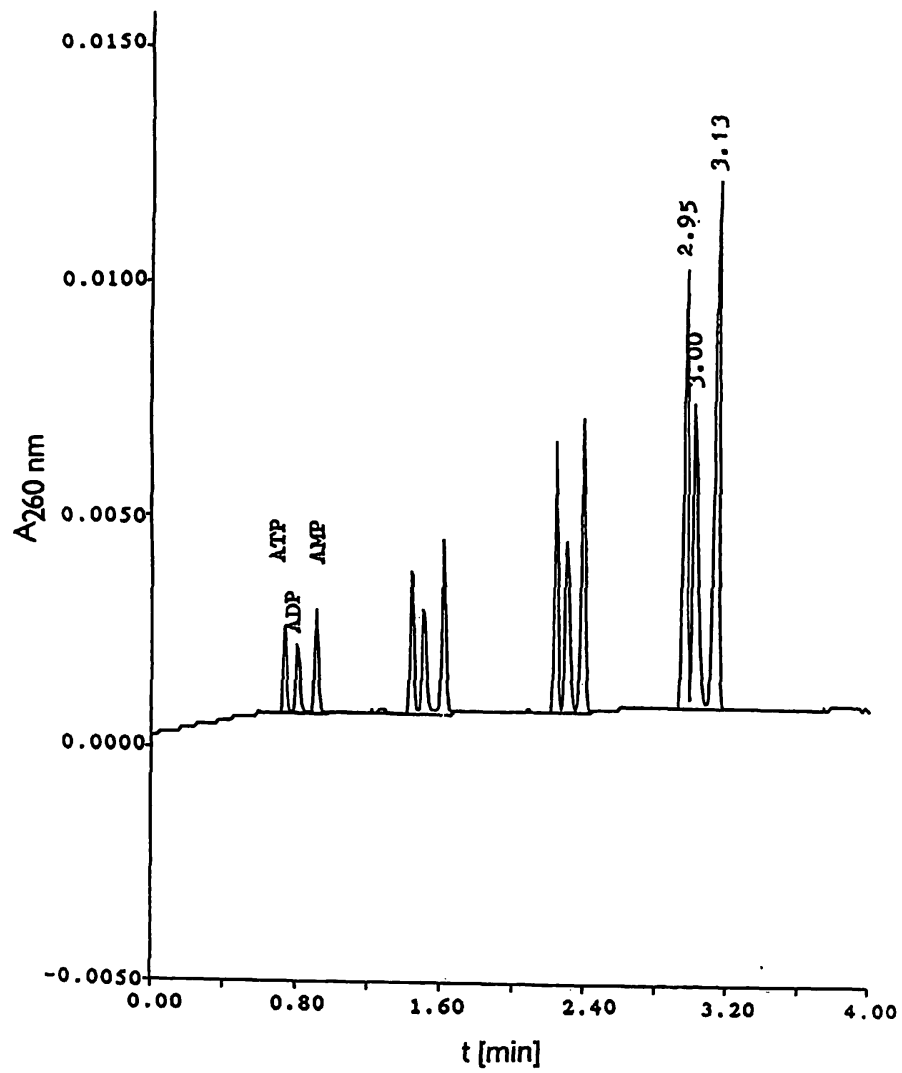

Fig. 2a The analyses of ATP, ADP and AMP standard solutions. Concentrations see figure $2 \mathrm{~b}$. Separation conditions: coated silica capillary $(25 \mu \mathrm{m} \mathrm{I}$. D. $\times 24 \mathrm{~cm}, 19.4 \mathrm{~cm}$ to the window). Operational borate buffer $0.23 \mathrm{~mol} / \mathrm{l}, \mathrm{pH} 7.8$. Injection of sample $20 \mathrm{psi}$ $\left(14 \times 10^{3} \mathrm{~kg} / \mathrm{m}^{2}\right) \times \mathrm{s}, 20^{\circ} \mathrm{C}, 10 \mathrm{kV}$, polarity $\ominus \rightarrow \oplus$, detection wavelength $260 \mathrm{~nm}$. 


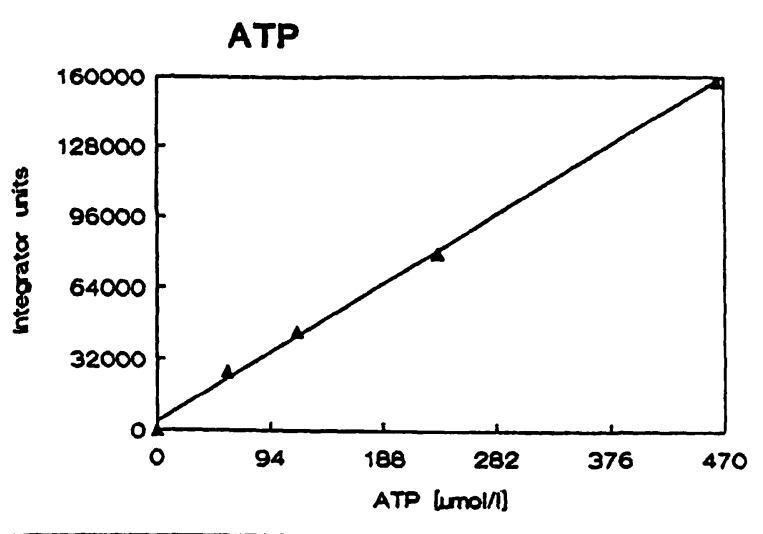

\begin{tabular}{lcc}
\hline No. & ATP $(\mu \mathrm{mol} / \mathrm{l})$ & Integrator units \\
\hline 1 & 0 & 0 \\
2 & 58 & 26393 \\
3 & 116 & 44511 \\
4 & 232 & 79900 \\
5 & 464 & 157725 \\
\hline
\end{tabular}

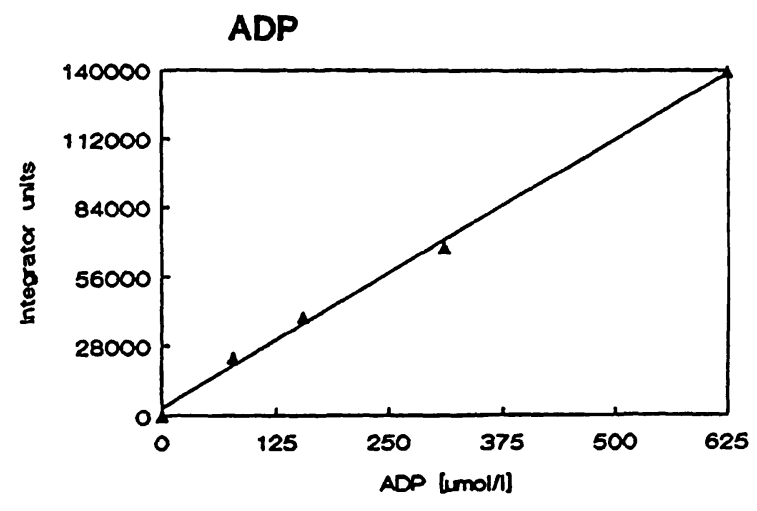

\begin{tabular}{lcc}
\hline No. & ADP $(\mu \mathrm{mol} / 1)$ & Integrator units \\
\hline 1 & 0 & 0 \\
2 & 78 & 23075 \\
3 & 156 & 39682 \\
4 & 312 & 67711 \\
5 & 624 & 139422 \\
\hline
\end{tabular}

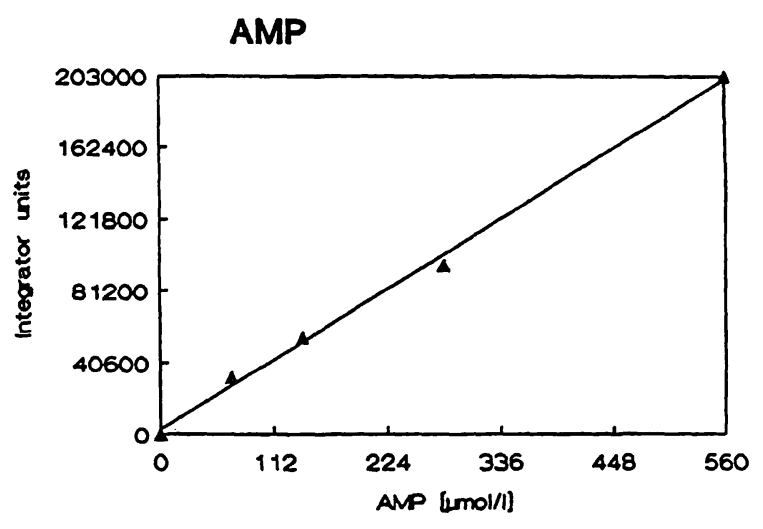

\begin{tabular}{lcc}
\hline No. & AMP $(\mu \mathrm{mol} / \mathrm{l})$ & Integrator units \\
\hline 1 & 0 & 0 \\
2 & 70 & 32297 \\
3 & 140 & 54959 \\
4 & 280 & 96046 \\
5 & 560 & 202806 \\
\hline
\end{tabular}

Fig. 2b Calibration graphs of ATP, ADP and AMP. Data from analyses see figure $2 a$.
Tab. 1 The migration times (mean \pm SD) and apparent electrophoretic mobilities $\left(\mu_{\text {app }}\right)$ of adenosine phosphates standard solutions separated by capillary zone clectrophoresis. For separation conditions and other data see figures $2 a, 2 b$.

\begin{tabular}{lll}
\hline Nucleotides & $\begin{array}{l}\text { Migration } \\
\text { time } \\
(\min ,\end{array}$ & $\mu_{\text {upp }}$ \\
& $\overline{\mathrm{x}} \pm \mathrm{SD})$ & $\begin{array}{l}10^{-4} \mathrm{~cm}^{2} \\
\mathrm{~V}^{-1} \mathrm{~s}^{-1}\end{array}$ \\
\hline Adenosine 5'-triphosphate disodium & $2.96 \pm 0.11$ & 2.62
\end{tabular}

salt $3 \mathrm{H}_{2} \mathrm{O} M_{\mathrm{r}} 605.2$,

Boehringer Mannheim (58-464 $\mu \mathrm{mol} / \mathrm{l})$

Adenosine 5'-diphosphate sodium $\quad 3.02 \pm 0.11 \quad 2.57$ salt $M_{\mathrm{r}} 449.2$,

SIGMA $(78-624 \mu \mathrm{mol} / \mathrm{l})$

Adenosine 5'-monophosphate disodium salt $6 \mathrm{H}_{2} \mathrm{O} M_{\mathrm{r}} 499.2$,

Boehringer Mannheim $(70-560 \mu \mathrm{mol} / \mathrm{l})$

Tab. 2 Migration times (mcan $\pm S D, n=7$ ) reproducibility of migration times and peak arca of nucleotides in whole blood. Separation conditions: coated silica capillary $(24 \mathrm{~cm} \times 25 \mu \mathrm{m}, 19.4 \mathrm{~cm}$ to window), $0.23 \mathrm{~mol} / \mathrm{l}$ borate buffer ( $\mathrm{pH} 7.8), 20^{\circ} \mathrm{C}, 20 \mathrm{kV}$, sample injection $20 \mathrm{psi}\left(14 \times 10^{3} \mathrm{~kg} / \mathrm{m}^{2}\right) \times \mathrm{s}$, electrode polarity $\theta \rightarrow \oplus$, detection wavelength $260 \mathrm{~nm}$.

\begin{tabular}{llll}
\hline Nucleotide & $\begin{array}{l}\text { Migration time } \\
(\min , \overline{\mathrm{x}} \pm \mathrm{SD})\end{array}$ & $\begin{array}{l}\text { Reproduc- } \\
\text { ibility of } \\
\text { migration } \\
\text { time (\%) }\end{array}$ & $\begin{array}{l}\text { Peak } \\
\text { area }\end{array}$ \\
$\mathrm{CV}(\%)$ \\
\hline ATP & $1.57 \pm 0.038$ & 2.55 & 5.59 \\
ADP & $1.62 \pm 0.041$ & 2.53 & 5.32 \\
AMP & $1.67 \pm 0.041$ & 2.44 & 5.64 \\
\hline
\end{tabular}

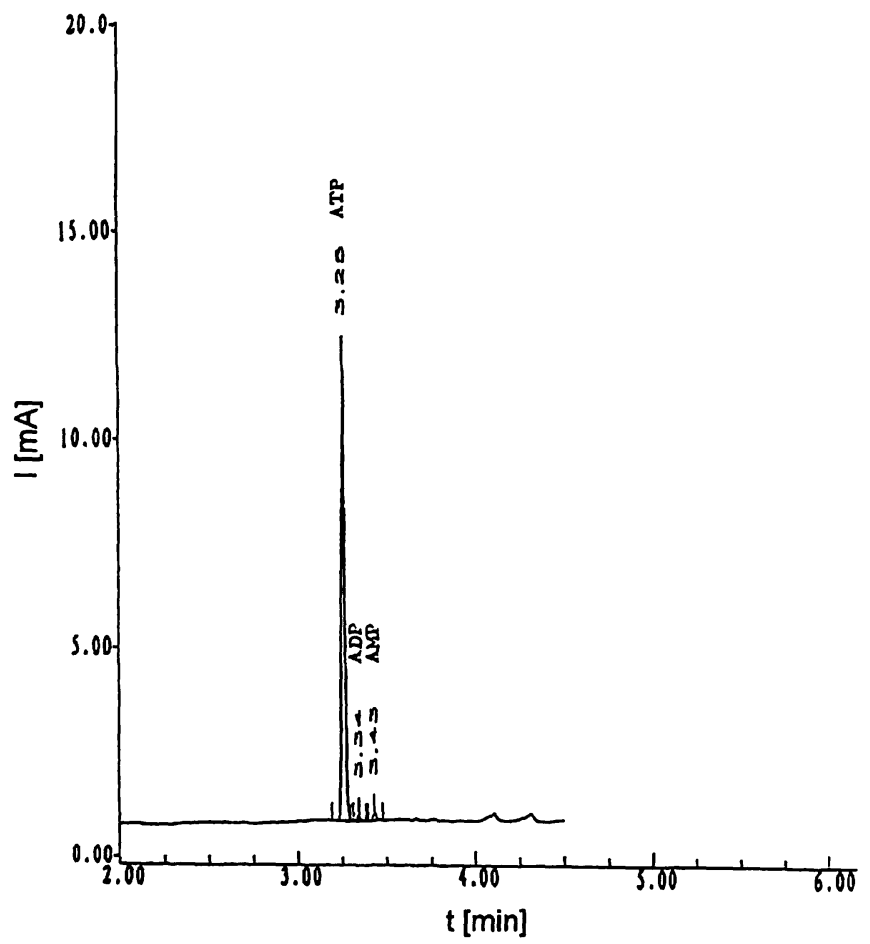

Fig. 3 The analysis of ATP in a mixture of ATP standard solution $(428 \mu \mathrm{mol} / \mathrm{l})$ and blood deproteinate with ATP concentration 393 $\mu \mathrm{mol} / 1(1: 1)$. The fusion of the analyte peak from blood deproteinate together with the pure ATP preparation peak gives evidence of identity of these components. For analysis conditions see figure $2 \mathrm{a}$. 
Tab. 3 Concentrations of nuclcotides in whole cord blood from newborns immediately after birth. Clinical data of seven full-term

\begin{tabular}{llllll}
$\begin{array}{l}\text { newborns immediately after birth. Clinical data of seven full-term } \\
\text { Gestational age } \\
\text { (weeks) }\end{array}$ & $\begin{array}{l}\text { Birth mass } \\
(\mathrm{g})\end{array}$ & Apgar score & $\begin{array}{l}\text { ATP } \\
\mu \mathrm{mol} / 1\end{array}$ & $\begin{array}{l}\text { ADP } \\
\mu \mathrm{mol} / 1\end{array}$ & $\begin{array}{l}\text { AMP } \\
\mu \mathrm{mol} / 1\end{array}$ \\
\hline & & & & $68 \pm 59$ & $46 \pm 14$ \\
$40.0 \pm 1.1$ & $3310 \pm 292$ & $\begin{array}{r}1 \min 7.4 \pm 1.8 \\
5 \min 8.6 \pm 1.4 \\
10 \min 9.3 \pm 0.7\end{array}$ & $467 \pm 134$ & \\
\hline
\end{tabular}

tides examined can be confirmed by the addition of internal standards of relevant pure nucleotides to the blood deproteinates, resulting in fusion of both analytes in the single peak (fig. 3). The application of the method is illustrated by the determination of ATP, ADP and AMP (mean \pm SD) in cord blood from seven full-term newborns delivered after normal pregnancies without signs of perinatal asphyxia (tab. 3). The nucleotide concentrations determined in whole blood agree with the findings of other workers (7). The method provides a detection limit for adenosine nucleotides of about $5 \mu \mathrm{mol} / 1$. The results of two electrophoretic analyses from one physiologic newborn (fig. 4) and from another preterm newborn infant with perinatal asphyxia are demonstrated (fig. 5). The latter, with perinatal asphyxia, shows a corresponding significantly decreased ATP concentration. In spite of the ATP, ADP and AMP contents in blood, deproteinates from physiological newborns exhibit wide ranges, still the decreased ATP concentration serves as a useful indicator of threatening or persisting hypoxia.

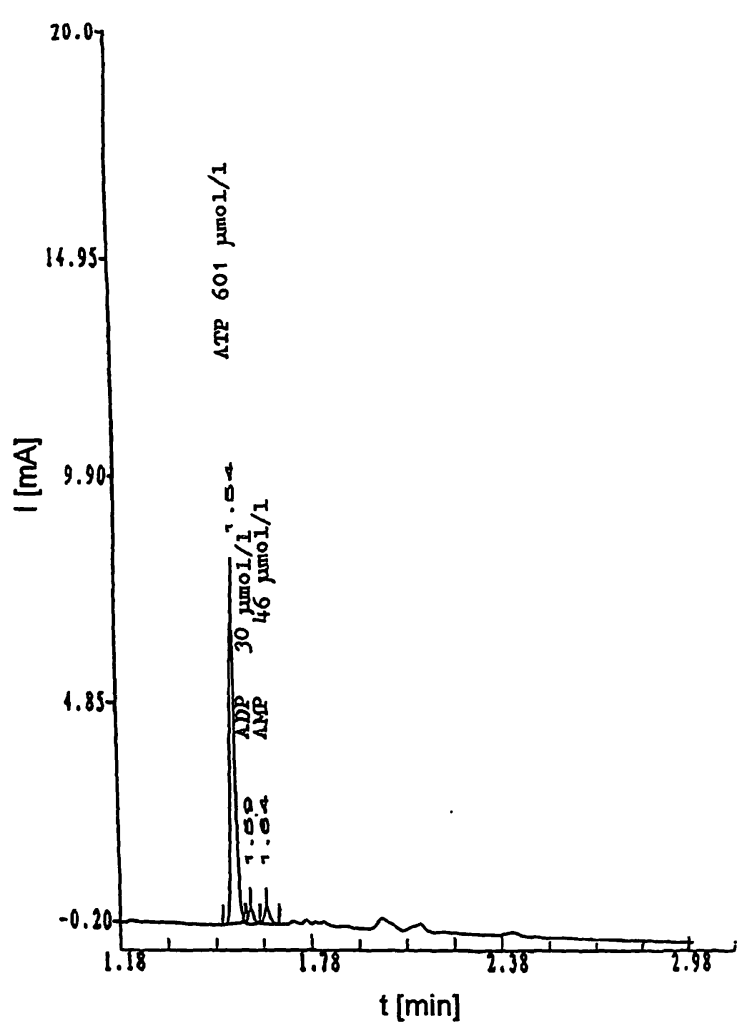

Fig. 4 The adenosine phosphates in cord blood, delivery of the full-term newborn in the $40^{\text {th }}$ week of pregnancy, body mass $3300 \mathrm{~g}$, transient hyperbilirubinaemia, phototherapy for $20 \mathrm{~h}$, breastfed, discharged on the $5^{\text {th }}$ day without complications. For separation conditions see figure $1 \mathrm{a}$.

\section{Discussion}

The occurrence of purine nucleotides in blood depends on the content in red cells and platelets, whereas plasma under normal conditions does not contain any of these compounds. According to our first experience the decrease of ATP during hypoxaemia does not correlate with the red cell and platelet count but rather with the extent of asphyxia. The earlier studies on the concentration of nucleotides in blood do not take into account the counts of red cells and platelets (7).

The analyses recorded in figures 1,4 and 5 were performed at the voltage $20 \mathrm{kV}$, while those in figures $2 \mathrm{a}$ and 3 were run at voltage $10 \mathrm{kV}$. Higher voltages make it possible to shorten the time of analyses substantially even at the risk of shortening the life of the inner surface coating of the $25 \mu \mathrm{m}$ inside diameter capillary.

Capillary electrophoresis allows simultaneous and specific determination of adenosine phosphates in whole blood with a single analysis, which could not be reached

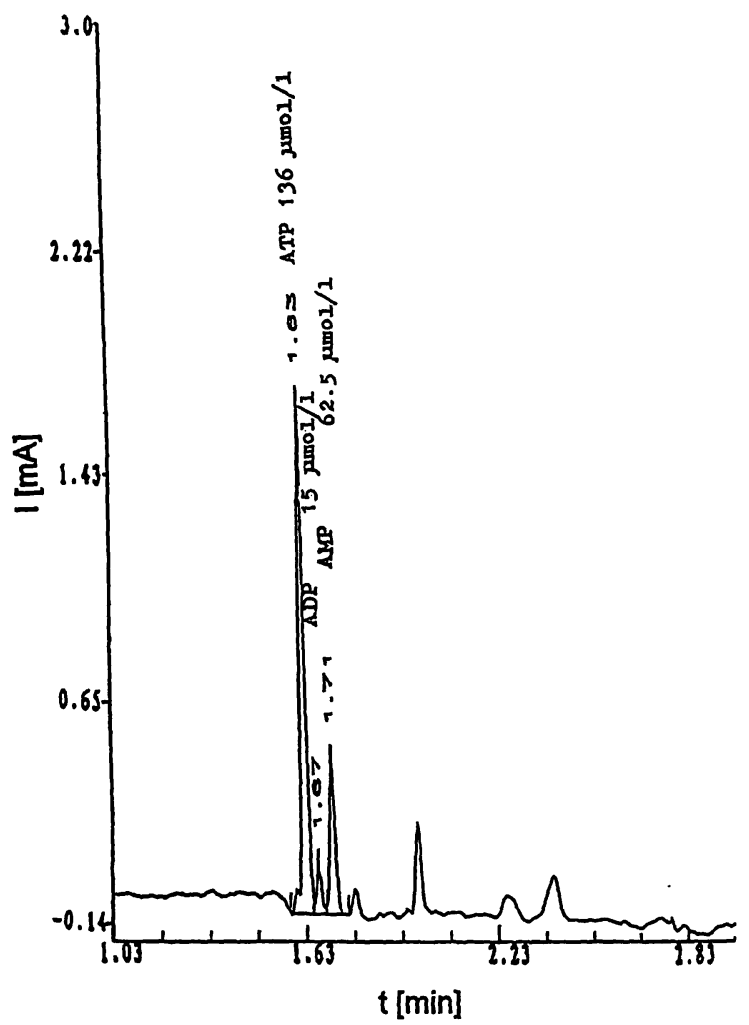

Fig. 5 The adenosine phosphates in cord blood, delivery of preterm baby in the $36^{\text {th }}$ week of pregnancy. Body mass $2600 \mathrm{~g}$, asphyxia, hypoxia intra partum, icterus neonatorum, oxygenotherapy for $24 \mathrm{~h}$, hospitalized for 12 days. For separation conditions see figure $1 \mathrm{a}$. 
with either the enzyme or bioluminescent methods. It provides useful information about the pool of chemical energy within an organism and thus enables monitoring of unusual metabolic situations. Capillary electrophoresis represents a new potentially important separation technique because it brings speed, quantitation, reprodu-

\section{References}

1. Janssens D, Michiels C, Delane E, Eliaers F, Drieu K, Remacle J. Protection of hypoxia-induced ATP decrease in endothelial cells by Ginkgo biloba extract and bilobalide. Biochem Pharmacol 1995; 7:991-9.

2. Kamarýt J, Muchová M, Stejskal J. Determination of adenosine phosphates in whole blood by capillary zone electrophoresis. In: Martin SM, Halloran SP, editors. Proceedings of the XVI International Congress of Clinical Chemistry 1996 July 8-12, London 1996. Piggot Printers Limited, Cambridge 1996:428.

3. Grune T, Ross GA, Schmidt H, Siems W, Perrett D. Optimized separation of purine bases and nucleosides in human cord plasma by capillary zone electrophoresis. J Chromatogr 1993; 635:105-11.

4. Dawson JE, Nichols SC, Taylor GE. Determination of impurities in a novel analogue of adenosine-5'-triphosphate by capillary electrophoresis. J Chromatogr 1995; A700:163-72. cibility and automation to the inherently resolving technique of electrophoresis.

\section{Acknowledgements}

The study has been supported by Grant No. 302/93/2534 from Grant Agency of Czech Republic.

5. BioFocus Capillary Electrophoresis System. Instruction Manual, Version 5.00, BIO-RAD Laboratories, CA, USA 1995.

6. Landers JP. Handbook of Capillary Electrophoresis. Boca Raton, Ann Arbor, London, Tokyo: CRC Press 1994.

7. Methods for Clinical Chemical Research. Biochemica Boehringer Mannheim 1988/1989; 20-5.

Received January 5/September 6, 1996

Corresponding author: J. Kamarýt, Ph. D., Research Institute of Child Health, Cernopolní 9, CZ-662 62 Brno, Czech Republic 
